\title{
Type 2 Diabetes, Immunity and Cardiovascular Risk: A Complex Relationship
}

\author{
Daniela Pedicino, Ada Francesca Giglio, \\ Vincenzo Alessandro Galiffa, \\ Francesco Trotta and Giovanna Liuzzo
}

Additional information is available at the end of the chapter

http://dx.doi.org/10.5772/50611

\section{Introduction}

Diabetes mellitus (DM) is a group of metabolic diseases characterized by hyperglycemia resulting from defects in insulin secretion, insulin action, or both. The chronic hyperglycemia of diabetes is associated with long-term damage, dysfunction, and failure of various organs, especially the eyes, kidneys, nerves, heart, and blood vessels (Expert Committee on the Diagnosis and Classification of Diabetes Mellitus, 1997, 2003)

\section{Epidemiology}

Diabetes is one of the most common chronic diseases in the world. It is thought that more than 360 million persons will be affected by this disease in 2030 (Wild et al., 2004). Prevalence of diabetes is higher in western countries because of the increasing of population age, physical inactivity and obesity, however it is rapidly spreading also in developing countries due to the socio-economic growth with progressive urbanization and changes in lifestyle.

Cardiovascular disease (CVD) in diabetic patients is characterized by microvascular damage, associated with the development of diabetic retinopathy, nephropathy, and neuropathy, and macrovascular complications linked to the accelerated course of atherosclerosis shown in these patients. Coronary heart disease (CHD) remains the principal cause of morbidity and mortality, in association with an increased risk of developing cerebrovascular disease, peripheral vascular disease and heart failure. 


\section{Classification and pathogenesis (Expert Committee on the Diagnosis and Classification of Diabetes Mellitus, 1997)}

$\mathrm{DM}$ is classified on the basis of pathogenetic mechanisms leading to hyperglycemia:

- Type 1, due to a virtually complete lack of endogenous pancreatic insulin production caused by an immune-mediated destruction of pancreatic beta cells (Immunomediated Type I diabetes), or by unknown mechanisms (Idiopatic Type I diabetes);

- $\quad$ Type 2, accounting for $\sim 90-95 \%$ of diabetic patients. Its complex pathogenesis, resulting from a combination of genetic predisposition, unhealthy diet, physical inactivity, and increasing weight with a central distribution of the adipose tissue leads to insulin resistance and usually relative (rather than absolute) insulin deficiency;

- Other specific types of diabetes, related to genetic defects of insulin secretion and/or action in peripheral tissues, endocrinophaties, or infections;

- Gestational DM.

Immune system and autoimmunity play a pivotal role in the pathogenesis of type 1 diabetes mellitus (T1DM) (Atkinson \& Maclaren, 1994), however inflammation may play a crucial intermediary role also in type 2 diabetes mellitus (T2DM) (Mykkänen, 2000) and in the development of its complications, including cardiovascular disease, thus linking it with several coexisting conditions thought to originate through inflammatory mechanisms.

\section{Inflammation, diabetes and cardiovascular risk}

Epidemiological studies conducted at the end of 1970 described diabetes as a major independent risk factor for cardiovascular disease, causing 2-4 folds increase in cardiovascular risk (Kannel \& McGee, 1979). Atherosclerosis is responsible for the $80 \%$ of deaths in diabetic patients ( $\mathrm{Gu} \mathrm{K}$ et al., 1998)7, and diabetes is considered a "coronary disease equivalent", since several studies pointed out that diabetes-associated CV risk is similar to that observed among non-diabetic patients with prior myocardial infarction (MI) (Haffner et al., 1998; Schramm et al., 2008).

Diabetes is associated with an increased risk of MI and affects more than $30 \%$ of patients with acute coronary syndromes (ACS) (Fang \& Alderman, 2006). Diabetic patients show a worse outcome after ACS events (Malmberg et al., 2000; Murcia et al., 2004), a more complicated course of the disease and a higher incidence of ischemic recurrences (Cantrill et al., 1995; Miettinem et al., 1998; Shindler et al., 2000). Moreover, if undergoing revascularization procedures, they have a worse prognosis than patients without diabetes (Banning et al., 2010; Hlatky et al., 2009).

Several angiographic studies highlighted a greater spread and progression of atherosclerotic disease in diabetes patients. Moreover, histological specimens of atherosclerotic plaques obtained in diabetic patients exhibit larger lipid core, a higher inflammatory cell infiltration and increased neovascularization (Burke et al., 2004; Moreno \& Fuster, 2004). 
Since the isolated treatment of hyperglycemia has not been associated to a reduction of $\mathrm{CV}$ risk in diabetic people, more aggressive primary and secondary prevention measures are needed in these patients (ADVANCE Collaborative Group, 2008; UKPDS Group, 1998).

The early onset and the burden of macroangiopathy in diabetic patients have a multifactorial pathogenesis and are the result of very complex mechanisms including the coexistence of multiple risk factors, such as obesity, hypertension and dyslipidemia. Moreover hyperglycemia, insulin resistance, hyperinsulinemia and the presence of Advanced Glycation End-products (AGE) in plasma and vascular wall are all mechanisms involved in the establishment of a pro-inflammatory state characterized by the activation of inflammatory cells and cytokine production, leading to immune dysregulation and prothrombotic state.

On the other hand, inflammation can be considered a common link between these factors, being involved in each step of atherothrombosis, from the formation to the complications of the plaque, and in the metabolic dysregulation characterizing diabetes.

Several studies have demonstrated a correlation between T2DM, inflammation and innate immunity system. These evidences, together with more recent findings on inflammation and immune mechanisms, could pave the way to a new etiopathogenic hypothesis of Metabolic Syndrome and T2DM, firstly proposed by Pickup in 1997 (Pickup, 2004), and suggesting that activation of innate immunity, together with a chronic inflammatory response, could also play a pivotal and early role in causing diabetes, instead of being a mere consequence of hyperglycemia, hyperinsulinemia and obesity.

Recent evidences have also shown that adaptive immunity and autoreactivity could play a role in the pathogenesis of T2DM and in its complications (Figure 1).

\section{Diabetes and innate immunity}

\subsection{Systemic markers of inflammation}

Established T2DM is associated with elevated circulating biomarkers of innate immunity activation, including C-reactive protein (CRP) and interleukin (IL)-6 and these alterations are also present in patients with pre-diabetes and metabolic syndrome. In fact several crosssectional studies in non-diabetic subjects, in the general population (Festa et al., 2000; Ford, 1999a, 1999b; Frohlich et al., 2000; Hak et al., 2001; Sakkinen et al., 2000; Yudkin et al., 1999; Visser et al., 1999; Weyer et al., 2002) ${ }^{23-31}$, or in individuals with impaired glucose tolerance (IGT)/impaired fasting glucose (IFG) (Muller et al. 2002;, 2002b, Sriharan et al., 2002), have confirmed that acute-phase reactants are positively correlated with measures of insulin resistance, plasma insulin concentration, BMI, waist circumference, and circulating triglyceride, and negatively correlated with HDL cholesterol concentration.

Additional cross-sectional studies in newly diagnosed (Temelkova-Kurktschiev et al., 2002) or established T2DM patients (Arnalich et al., 2000; Leinonen et al., 2003; Richarsdon \& Tayek, 2002; Rodriguez-Moran \& Guerrero-Romero, 1999) have confirmed that acute-phase 


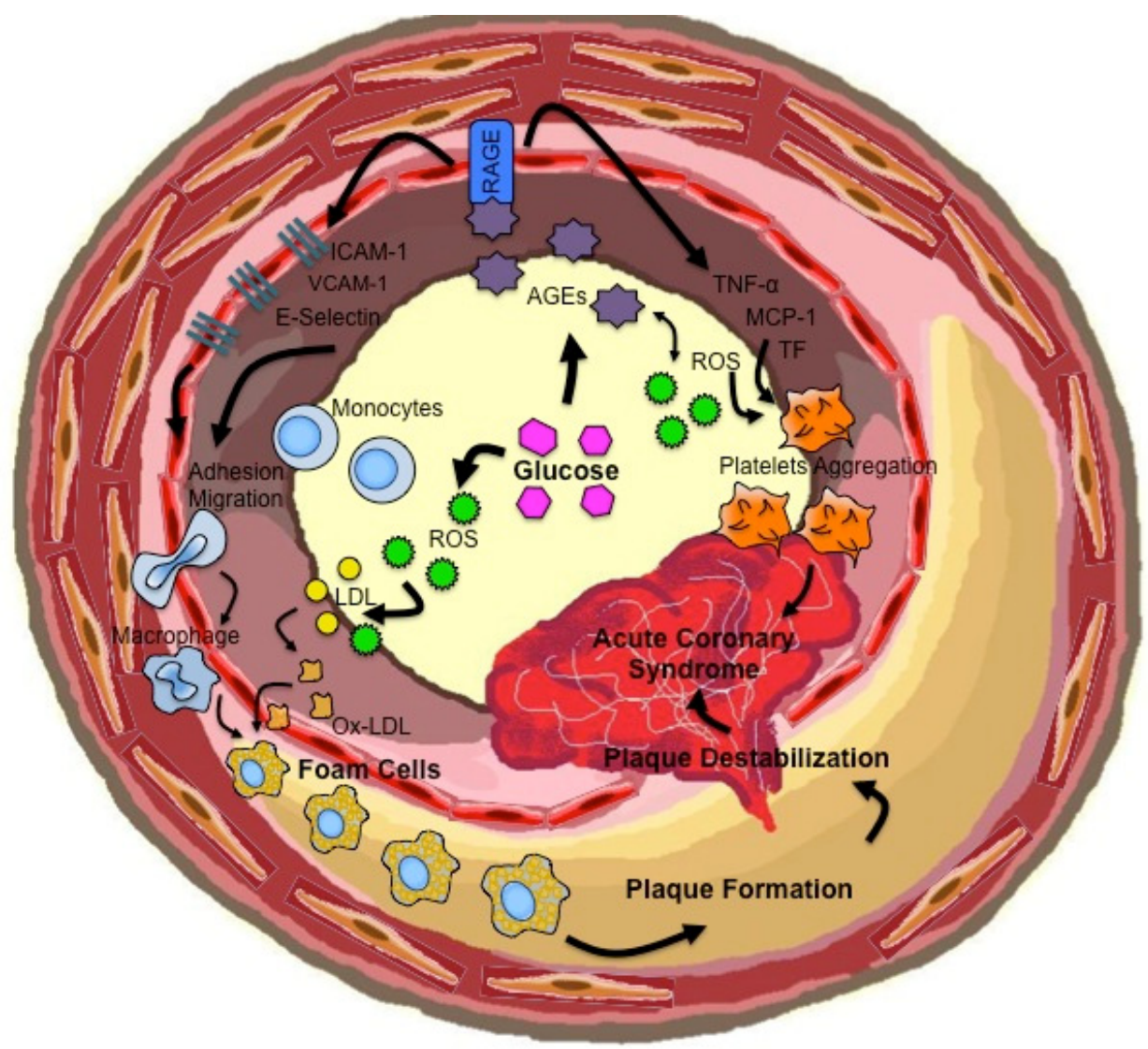

Figure 1. Schematic representation of the principal mechanisms linking diabetes, vascular injury and atherosclerotic disease. Hyperglycemia induces formation of advanced glycation end products (AGEs) that bind to their receptors (RAGE) present on endothelial cells, smooth muscle cells, monocytes and macrophages, thus promoting vascular inflammation, endothelial dysfunction, and prothrombotic state. Hyperglycemia and AGEs also cause generation of reactive oxygen species (ROS), which in turn increase AGE and oxidized low-density lipoproteins (ox-LDL) formation. These pathways are all involved in the development of atherosclerosis and plaque progression/destabilization in diabetic patients.

markers such as CRP and IL-6 are elevated in these subjects compared with non-diabetic controls (Katsuki et al., 1998; Pickup et al., 2000; Winkler et al., 1998).

On the other side it has been shown how abnormal circulating levels of acute-phase reactants, in particular CRP and serum amyloid A, and inflammatory cytokines like IL-6, are good predictor of the development of T2DM in nondiabetic subjects. Schmidt and colleagues (Duncan et al., 1999; Schmidt et al., 1999), using data from the Atherosclerosis Risk in Communities study, showed for the first time that inflammatory markers, such as white blood cell count, low serum albumin, $\alpha 1$-acid glycoprotein, fibrinogen, and sialic acid, 
predict the development of T2DM and this has been confirmed by several follow-up studies in different populations (Table 1).

\begin{tabular}{|c|c|c|c|c|}
\hline Authors & Year & $\begin{array}{l}\text { Inflammatory } \\
\text { marker(s) analized }\end{array}$ & Subjects & $\begin{array}{l}\text { Follow-up } \\
\text { (years) }\end{array}$ \\
\hline Pradhan et al. & 2001 & CRP and IL-6 & US women & 4 \\
\hline Barzilay et al. & 2001 & CRP & $\begin{array}{l}\text { US men and } \\
\text { women }\end{array}$ & $3-4$ \\
\hline Vozarova et al. & 2002 & White blood count & Pima Indians & 5,5 \\
\hline Festa et al. & 2002 & $\begin{array}{l}\text { CRP, fibrinogen, and } \\
\text { PAI-1 }\end{array}$ & $\begin{array}{l}\text { Multiethnic } \\
\text { subjects }\end{array}$ & 5 \\
\hline Freeman et al. & 2002 & CRP & Scottish men & 5 \\
\hline Ford et al. & 2002 & White blood count & $\begin{array}{l}\text { US men and } \\
\text { women }\end{array}$ & 20 \\
\hline Nakanishi et al. & 2002 & White blood count & Japanese men & 6 \\
\hline Snijder et al. & 2001 & CRP & $\begin{array}{l}\text { Dutch men and } \\
\text { women }\end{array}$ & 6 \\
\hline Spranger et al. & 2003 & $\begin{array}{l}\text { IL-6, with additional } \\
\text { risk of IL- } 6 \text { and IL-1 } \\
\text { combined }\end{array}$ & $\begin{array}{l}\text { German men } \\
\text { and women }\end{array}$ & 2.3 \\
\hline Thorand et al. & 2003 & CRP & $\begin{array}{l}\text { German middle- } \\
\text { aged men and } \\
\text { women }\end{array}$ & 7.2 \\
\hline
\end{tabular}

Legend: CRP, C-reactive protein; IL, interleukin; PAI, plasminogen activator inhibitor.

Table 1. Inflammatory markers and the prediction of T2DM development

The association between altered levels of acute-phase reactants and the development of diabetes is generally independent of age, sex, blood glucose concentration, family history of diabetes, physical activity, smoking, and baseline atherosclerosis, while it seems to be weaker if adjusted for obesity (Pickup, 2004).

It has been shown that treatment with high doses of aspirin is associated with a $25 \%$ reduction in fasting plasma glucose, a $50 \%$ reduction in triglycerides and a $15 \%$ decrease of total cholesterol and CRP, even if no change in body weight occurs (Hundal et al., 2002).

Recent studies have shown a role played by genetic variations in influencing the innate immune response and the risk of developing T2DM, obesity and atherosclerosis (FernandezReal \& Pickup, 2008). These variations can relate to genes encoding proteins like inflammatory markers, cytokines and cellular pattern-recognition receptors (PRR). 
Genetic predisposition to high transcription rate of TNF- $\alpha$ and IL-6 genes is associated with an increased risk of developing obesity, insulin-resistance and diabetes (Fernandez-Real \& Ricart, 2003).

Increased levels of inflammatory markers and insulin resistance have been also connected to a genetically determined reduction of serum levels of soluble CD14, a molecule expressed by macrophages able to bind lipopolysaccharide (LPS), and Bactericidal and Permeability Increasing protein (BPI), produced by neutrophils (Fernandez-Real et al., 2003; Gubern, 2006).

Moreover, decreased levels of mannose-binding lectine (MBL), a protein involved in the clearance of infectious pathogens through the induction of complement activation and macrophage phagocytosis, have been associated both with a raised risk of infections (Summerfield et al., 1997), CHD (Best et al., 2004), obesity and insulin resistance (FernandezReal et al, 2006).

\subsection{Toll like receptors as link between inflammation and metabolic diseases}

Mechanisms by which the activation of the innate immunity can cause insulin resistance have been clarified recently; many studies have revealed how TNF- $\alpha$ could activate the cJun NH2-terminal kinase, a stress-induced kinase which serinephosphorylates many signaling proteins, including insulin receptor substrate (IRS)-1 and IRS-2, thereby inhibiting insulin signaling (Morris et al., 2003).

A crucial role, in this setting, is probably played by Toll-like receptors (TLR). TLR are key receptors of innate immunity recognizing a huge number of molecules usually expressed by pathogen microorganisms but absent in mammal tissues, named pathogen-associated molecular patterns (PAMPs), and other molecules called damage-activated molecular patterns (DAMPs); therefore TLR belong to the family of PRR (Kawai \& Akira, 2010).

To date, 13 TLRs have been described, both located on the extracellular surface or in the intracellular compartment (Takeda \& Akira, 2004). Among them, TLR2 and TLR4 have been associated with metabolic disorders, as well as with atherosclerosis and its clinical manifestations. TLR2 and TLR4 loss-of-function, absence or inhibition in high-fat diet murine models has been related to a decrease in weight gain, insulin resistance and betacells dysfunction (Caricilli et al., 2008; Ehses et al., 2010; Tsukumo et al., 2007). TLR4 is highly conserved and selectively activated by lipopolysaccharides (LPS), a constituent of Gram-negative bacterial cell-wall (Kawai \& Akira, 2010). Some authors have demonstrated how the lauric acid, a medium-chain fatty acid (FA) component of LPS, trigger TLR4 signaling in macrophages and have revealed how saturated FAs, but not unsaturated, activate inflammatory signals in adipose cells and macrophages (Lee et al., 2001, 2003). Other studies have proposed that the sphingolipid ceramide, synthesized from FAs, might represent a possible link between high-fat diet intake and TLR pathways. Indeed, sphingolipid ceramide is able to activate TLR4 signaling (Fischer et al., 2007; Schwartz et al, 2010), and the inibition of its biosynthesis improves glucose tolerance in murine models 
(Holland et al., 2007). However, the previously described studies have not adequately eliminated potential contamination of the reagents used in the experimental condition with bacterial products. Therefore, the direct stimulation of TLRs in various cell types attributed to saturated FAs might be due to LPS contamination (Erridge \& Samani, 2009).

The expression in the vessel wall of both TLR2 and TLR4 has a synergistic effect on the progression of atherosclerotic plaque (Monaco et al., 2009; Shinoara et al., 2007). TLR4, whose endogenous ligand is ox-LDL ( $\mathrm{Xu}$ et al., 2001), is highly expressed in SMC of atherosclerotic vessels, where it has been associated with the induction of a proinflammatory phenotype (Loppnow et al., 2008; Otsui et al., 2007). Furthermore, TLR4 has been found in atherosclerotic lesions and at the site of plaque rupture in patients with MI (Ishikawa et al., 2008), and its expression is increased in thrombi from patients with acute coronary syndromes (Wyss et al., 2010; Yonekawa et al., 2011). Moreover, several studies showed that circulating monocytes of patients with atherosclerotic disease exhibit higher expression of TLR2 and TLR4 as compared to healthy individuals (Geng et al., 2006; Kuwahata et al., 2010; Mizoguchi et al., 2007; Shiraki et al., 2006), and an enhanced TLR signaling has been demonstrated in monocytes of patients with ACS (Ashida et al., 2005; Methe et al., 2005; Versteeg et al., 2008).

To date, the mechanisms linking high-fat diets with TLR-signaling and associated pathologies, such as atherosclerosis and insulin resistance, remain to be discovered. As an alternative TLR-dependent mechanism, currently under investigation, the large quantities of lipopeptide and LPS derived from the commensal organisms of the mammalian intestine may contribute to systemic stimulation of TLR2 or TLR4 signaling. Administration of LPS in mice has been associated with an increase of hepatic insulin resistance and a decrease of glucose tolerance (Arkan et al., 2005; Cani et al., 2007). It has been shown that blood levels of LPS are higher in T2DM patients than in healthy controls and correlate with insulin levels and glucose ( Al-Attas et al., 2009; Creely et al., 2007; Harte et al., 2010). Hence, an increased level of PAMPs like LPS may play an important role in the development of the inflammatory status characterizing metabolic diseases like T2DM.

Main sources of PAMPs are represented by infections, commensals and diet (Erridge, 2011). It's difficult to assess the quantitative contribution of each of them to PAMPs burden in humans, but increasing evidences are demonstrating that, under certain conditions like high fat meals, PAMPs derived from commensals and diet can effectively translocate from the intestinal lumen to the circulation (Erridge et al, 2007; Laugerette et al., 2010). Indeed, it has been widely demonstrated that oral microorganisms and human periodontitis are associated with an increased risk of developing atherosclerosis and T2DM (Bahekar et al., 2007). The small intestine seems to be the main contributor of the global circulating PAMPs burden, mostly due to the absorption of PAMPs swallowed from the oral cavity. This is probably due to the bigger surface area compared to large intestine and the fat-soluble nature of PAMPs such as LPS, accounting for their easier absorption in chylomicrons with dietary fat, a process taking place only in the small intestine (Ghoshal et al., 2009). Moreover, it is reasonable that the most part of PAMPs absorbed in the large intestine firstly reach liver through the portal system, being there effectively removed from circulation; on the other 
hand, PAMPs from the small intestine, through chylomicrons absorption, can reach lymphatic system and general circulation bypassing the liver. Finally a quote of PAMPs may come from diet. Interestingly, it has been demonstrated that PAMPs are nearly absent in fresh food, but they can be copious in a number of processed food typical of Western diet, such as meat and dairy products (Erridge, 2010, 2011).

\subsection{Role of inflammasomes in peripheral insulin resistance}

Recent studies also highlighted a crucial role of inflammasomes pathways both in insulin production and in insulin sensitivity.

Inflammasomes are group of protein complexes which recognize a diverse set of inflammation-inducing stimuli, including PAMPs, and DAMPs (Strowig et al., 2012). The activation of these complexes lead to the proteolitic activation of caspase- 1 and, finally, to the production and release of important pro-inflammatory cytokines such as IL-1 $\beta$ and IL-18 (Davis et al., 2011; Schroder \& Tschopp, 2010). The most widely studied inflammasome is the NLRP3 inflammasome, which could be activated by a large variety of signals, included PAMPs, DAMPs and bacterial toxins.

A two-step process is required to induce NLRP3 inflammasome activation. A first priming step is usually mediated by PRRs, such as TLR, or cytokines receptors known to induce activation of $\mathrm{NFkB}$, and leads to production and intracellular release of inactive forms of NLRP3. A subsequent activation step induces the inflammasome assembly; it starts in response to a variety of stimuli, such as potassium efflux, extracellular ATP, reactive oxygen species (ROS) and rupture of lysosomal membrane integrity, and leads to caspase-1 activation and cleavage of pro-IL1 $\beta$. Recent evidences suggest that NLRP3 play a pivotal role both in the early stages and in the chronic progression of T2DM (Kahn et al., 2006). Vandanmagsar et al. found that NLRP3 inflammasome is largely expressed in adipose-tissue-infiltrating macrophages, and it is activated by obesity-associated 'danger-signals', such as the saturated fatty acid palmitate and lipotoxicity-associated ceramide (Vandanmagscar et al., 2011). They also demonstrated how the expression of NLPR3 in the adipose tissue is directly correlated to insulin resistance both in mice and humans and that blockade of NLRP3 could reduce inflammation and improve insulin sensitivity (Vandanmagscar et al., 2011). Other studies demonstrated that during obesity, circulating free fatty acids are scavenged by adipose tissue macrophages to produce ceramide ( Shah et al., 2008) and confirmed the role of this lipid molecule in inducing NLRP3 inflammasome activation (Boden \& Ceramide, 2008). IL-1 $\beta$, produced as a result of inflammasome activation, inhibits insulin signaling (Wen et al., 2011) by direct serine phosphorylation of IRS- 1 and induces the expression of TNF- $\alpha$ (Strowig et al, 2012), an insulin-resistance-promoting cytokine as discussed above. IL-1 $\beta$ and IL-18 also induce type $1 \mathrm{CD} 4^{+} \mathrm{T}$-helper cells differentiation in adipose tissue (Vandanmagscar et al., 2011). Moreover, the activation of caspase- 1 seems to be related also to adipocytes differentiation and adipokines production (Stienstra et al., 2011).

Inflammasome activation is also involved in impaired insulin secretion associated with overt T2DM. Human $\beta$-cells are capable to produce IL-1 $\beta$ when exposed to elevated glucose 
concentration (Maedler et al., 2002). Several models have been proposed to explain the inflammasome mediated pancreatic islets dysfunction and particularly the role of ROS induced inflammasome activation has been highlighted. Hyperglycemia stimulates mitochondrial ROS production by increasing the activity of the electron transport chain, leading to the activation of NLRP3. Thioredoxin-interacting protein (TXNIP) is usually bound to oxidoreductase thioredoxin, however, when intracellular ROS increase, it seems to act as an upstream specific activating lingand for NLRP3. TXNIP expression is induced by glucose (Oka et al., 2009) and repressed by insulin (Parikh et al., 2007). Moreover, glucose induces the expression of TXNIP in pancreatic islets but not in macrophages(Zhou et al., 2010) and glucose dependent IL-1 $\beta$ secretion in pancreatic islets is inhibited in TXNIP- and NLRP3-knockout mice and antagonized by ROS-blockers. Taken together, these evidences suggest that a chronic condition of high plasmatic glucose levels induces pancreatic islets dysfunction through a mechanisms involving TXNIP-dependent NLRP3 inflammasome and that, once activated, this inflammasome could represent an adjunctive and self-maintaining immune-metabolic stressor.

Hystopathological studies recently showed deposition of islet amyloid polypeptide (IAPP, also known as amylin) in pancreatic islets of T2DM patients (Seino et al., 2001), that seems to be able to specifically activate the NLRP3 inflammasome through a mechanism that involves disruption of the phagolysosomal pathway (Masters et al., 2010).

Additional support for a pathological role of inflammasomes in T2DM comes from human clinical trials in which blockade of IL- $1 \beta$ signaling by Anakinra, a recombinant human IL-1 receptor antagonist (IL-1RA) demonstrated sustained reduction of inflammation, improved glycaemic control and $\beta$-cell function in T2DM patients (Dinarello et al., 2010; Larsen et al., 2007).

Moreover inflammatory cytokines such as TNF- $\alpha$, IL-1 $\beta$, and IL-6 also downregulate peroxisome proliferator activated receptor- $\gamma$ (PPAR- $\gamma$ ) expression (Tanaka et al., 1999). PPAR- $\gamma$ is a ligand-activated transcription factor highly expressed in adipose tissue, where it controls adipocyte differentiation and lipid storage, and modulates insulin action. It represents the target of thiazolidinediones (TZDs) pioglitazone and rosiglitazone, which are demonstrated to improve glycemic control and insulin-sensitivity and to reduce T2DMassociated inflammation (Miyazaki et al., 2001a, 2001b) ) $^{120,121}$.

As noted above, much evidence suggests an intimate relationship among IL-1 $\beta$, the NLRP3 inflammasome and the metabolism of lipids and carbohydrates. This occurs at the level of enhanced NLRP3 inflammasome activation and processing of IL-1 $\beta$ to the mature cytokine in response to saturated fatty acids and also at the level of glucose metabolism through the requirement of glycolysis for induction of IL-1 $\beta$ mRNA. The pathogenic role of IL-1 $\beta$ in atherosclerotic plaque formation and in insulin resistance in T2DM attests to the importance of inflammasome-mediated pathways as link between inflammation, T2DM and CVD. The exacerbation of NLRP3 inflammasome activation by cholesterol crystals in atherosclerosis (Duewell et al., 2010; Rajamäki et al, 2010) and by IAPP in type 2 diabetes (Masters et al., 2010), provides a positive feedback loop to promote disease pathogenesis. 
Taken together, these findings support a crucial role of different molecules and pathways of innate immunity in the complex metabolic imbalance underlining T2DM, and possible contributing to the disease-associated cardiovascular risk. Insight into the above described molecular pathways could help in the design of new therapeutic strategies.

\section{Diabetes and adaptive immunity}

In the past years, a possible role of adaptive immunity and autoreactive mechanisms in the pathogenesis of T2DM has probably been underestimated and, therefore, poorly investigated. However, increasing evidences support the role of autoimmunity and adaptive immune system in the pathogenesis of T2DM and its vascular complications (BrooksWorrell \& Palmer, 2012; Nikolajczyk et al, 2011). It has been recently demonstrated that Tlymphocytes of patients with T2DM produce large amounts of pro-inflammatory cytokines, such as IL-8, showing in contrast a decreased production of anti-inflammatory cytokines, such as IL-10 (Jagannathan et al., 2010). These functional alterations are consistent with those previously demonstrated in monocytes of T2DM patients (Giulietti et al., 2007; Hatanaka et al., 2006; Pitocco et al., 2009), and result in an imbalance of cytokines network and in a strongly pro-inflammatory environment. High pro-inflammatory cytokines production has been associated in several studies with insulin-resistance and DM development, while the inhibition of some pro-inflammatory mediators prevented insulinresistance in mice (Arkan et al., 2005; Cai et al., 2005; de Roos et al., 2009; Ehses et al., 2009; Reimers, 1998.

Moreover, the role of a perturbation of T-cell repertoire has been demonstrated in murine models of T2DM. Particularly, regulatory T-cells (Treg) are significantly diminished in the adipose tissue of obese insulin-resistant mice compared to non-obese animals. Treg cells isolated and expanded ex-vivo, in these models, were found able to exert an antiinflammatory activity and lessen insulin-resistance (Feuerer et al., 2009). On the other hand, Interferon (IFN)- $\gamma$-producing cells in the adipose tissue of obese mice may cause an imbalance in glucose homeostasis. The alterations mediated by T-cells with a Th1 phenotype, characterized by IFN- $\gamma$ production, can be counterbalanced by CD4+T-cells with an anti-inflammatory phenotype, such as Treg and Th2 lymphocytes producing IL-10 (Winer et al., 2009), thus underlining the importance of a physiological balance between different T-cells subset in the metabolic homeostasis of adipose tissue, which has a crucial role in the pathogenesis of insulin resistance and T2DM onset. Another cellular type possibly involved in inflammation and insulin-resistance in T2DM are IL-17 producing Tcells, so called Th17. This aggressive, pro-inflammatory T-cell subset has been found at high levels following IL-6 stimulation in the spleen of obese mice, and could contribute to the inflammatory environment strongly related to insulin resistance development and maintenance in T2DM (Winer et al., 2009). Consistently with this hypothesis, high levels of cytokines conditioning T-cell differentiation toward a Th17 phenotype, such as IL-6, IL-1 $\beta$ and Tranforming Growth Factor (TGF)- $\beta$, have been measured in diabetic patients (AcostaRodriguez et al., 2007; Andriankaja et., 2009; Osborn et al., 2008; Yang et al., 2008). These pro-inflammatory cytokines could promote Th17 cells expansion and inhibit Treg 
differentiation in T2DM patients. In recent years, a higher percentage of a particular T-cell type, $\mathrm{CD} 4^{+} \mathrm{CD} 28^{\text {null }} \mathrm{T}$ lymphocytes, has been found in diabetic patients undergoing microvascular complications, e.g. proliferative retinopathy (Canton et al., 2004). An expansion of this particular T-cell population, which is infrequent in healthy young people and slightly expanded in the elderly, has been detected in patients with unstable angina (Liuzzo et al., 1999, 2000); in this population, a percentage of CD4 $4^{+} \mathrm{CD} 28^{\text {null }} \mathrm{T}$-cells $>4 \%$, representing the $90^{\text {th }}$ percentile of distribution in healthy individuals, is associated with a poor outcome (Liuzzo et al., 2007). These cells have particular aggressive features, showing an increased IFN- $\gamma$ production and anti-apoptotic factors expression (Liuzzo et al., 2001), and could be involved in abrupt atherosclerotic plaque destabilization through several mechanisms. In fact, $\mathrm{CD} 4{ }^{+} \mathrm{CD} 28^{\text {null }} \mathrm{T}$-lymphocytes exert cytolitic effects on endothelial cells and express high levels of TNF-related apoptosis-inducing ligand (TRAIL), thus promoting smooth muscle cells apoptosis within the atherosclerotic plaque (Nakajima et al., 2002; Sato et al., 2006). With these premises, the recent finding of an expansion of CD4 ${ }^{+} \mathrm{CD} 28^{\text {null }} \mathrm{T}$-cells in diabetic patients is extremely interesting, suggesting a possible role of adaptive immune disregulation, either primary or induced by the altered metabolic status and the inflammatory environment characterizing the disease, in the increased cardiovascular risk which is one of the most relevant clinical features of T2DM, accounting for the majority of disease-related mortality and morbidity (Giubilato et al., 2011). Consistently, in the same study $\mathrm{CD}^{+} \mathrm{CD} 28^{\text {null }} \mathrm{T}$-lymphocytes expansion was closely related to a poor glycaemic control, and was associated with a higher incidence of cardiovascular events during followup.

Other fingerprints of adaptive immunity activation have been investigated in T2DM patients.

Increased activity of adenosine-deaminase (ADA) has been described in this population (Prakash et al., 2006). ADA is an enzyme that converts adenosine into inosine through an irreversible deamination reaction, and it is involved in T-cell proliferation and activation (Kather, 1990). Moreover, since adenosine increases glucose uptake into cells, an effect of ADA in reducing tissutal insulin sensitivity has been described (Gorrell et al., 2001). A recent study has confirmed an increased ADA activity in T2DM patients, underlining also an association between enzyme function and fasting glucose levels, as well as HbA1c. Thus, inflammation, T-lymphocytes activation and glucose metabolism seem to be tightly related in the complex setting of T2DM (Lee et al., 2011).

Tregs are another important T-cell type widely involved in autoreactive processes and in the modulation of the inflammatory environment associated with various diseases and pathological conditions. In the setting of diabetes mellitus, Tregs have been extensively investigated both in animal models and human patients with T1DM (Chatenoud et al., 2005, Randolph \& Fathman, 2006), while less studies have been performed on Tregs in T2DM. Interestingly, a recent study in mice demonstrated that Treg induction was associated to a reduction of adipose tissue inflammation and insulin resistance, with a concomitant improvement of metabolic parameters of lipid metabolism and glycaemic control (Ilan et al, 2010). Consistently, a subsequent study proved an inverse relation between Treg expression 
and function and insulin resistance in mice; Treg expansion was also associated with a reduction of signs of diabetes-related end-organ damage, such as nephropathy (Eller et al, 2011).

Finally, B-lymphocytes function has been poorly investigated in T2DM, but some data seem to indicate a role of these cells in the establishment and/or maintenance of a chronic proinflammatory state in this setting. For example, an altered B-cell activity related to cellular TLR dysfunction and leading to increased IL-8 and decreased IL-10 production has been recently demonstrated (Jagannathan et al, 2010).

Overall, these evidences suggest a diabetes-associated alteration of all components of adaptive immunity; these alterations could be implicated in the pathogenesis of the disease and, on the other hand, triggered and maintained by the disease itself, thus creating a proinflammatory, pro-atherosclerotic, vascular-damaging environment strongly associated with cardiovascular complications of T2DM.

\section{Treating T2DM by targeting immunity}

As a role of inflammation has been suggested in the development of diabetes and its vascular complications, TLRs and inflammasome could represent attractive drug targets. Several drugs currently adopted to control hyperglycemia and inflammation and improve prognosis in T2DM patients may also exert their effects on TLR-mediated pathways. For example, it has been shown that statin therapy reduces TLR2 and TLR4 expression (Methe et al., 2005; Niessner et al., 2006; Stoll et al., 2006). The role of PPAR- $\gamma$ agonists in inhibiting TLR activation both in vitro and in vivo has also been investigated (Dasu et al., 2009; Ji et al., 2009), as well as the ability of some angiotensin receptor blockers to decrease mRNA and protein levels of TLR2 and TLR4 (Dasu et al., 2009). However, although several molecules and drugs could potentially reduce inflammation associated with TLR signaling, studies on humans have to date shown a clear beneficial effect only related to statin therapy. Moreover, no drugs directly targeting TLRs have been developed.

For what concerns inflammasome's related pathways, the role of IL-1 $\beta$ in the impairment of pancreatic $\beta$-cell function, leading to apoptosis and decompensated insulin secretion, has prompted the use of anakinra in a double-blind clinical trial in patients with T2DM, that showed an improvement in $\beta$-cell secretory function, glycemia and inflammatory markers both during treatment and after drug withdrawal (Larsen et al., 2007, 2009).

A recent study tested in mice the efficacy of a high affinity monoclonal antibody to IL-1 $\beta$, XOMA 052, showing an inhibition of atherosclerotic plaques formation (Bhaskar et al., 2011). Although clinical trials testing this antibody in T2DM patients failed in demonstrating an improvement in glycemic control, XOMA 052 potentially might reduce cardiovascular risk, since its administration in diabetic patients was associated with a reduction of inflammatory markers and increased levels of high-density lipoprotein.

Furthermore, drugs directly targeting caspase- 1 have been tested in mice with promising results in reducing obesity and improving insulin sensitivity (Stienstra et al., 2010). 


\section{Conclusions}

Type 2 diabetes is a complex disease involving the whole metabolic profile of the organism and exerting pathological effects on several organs and systems. The disease is associated with a chronic low-grade inflammation predictive of, and possibly responsible for, many of the clinical signs and complications of T2DM. The diabetes-associated inflammatory status can be the consequence of the metabolic abnormalities characterizing the disease, but increasing evidences are proposing also an important role of immune system disregulation, involving both innate and adaptive immunity, in the pathogenesis of T2DM. Cellular homeostasis is strictly dependent on the cross talk between immune system and metabolic regulators. Hence, any imbalances between them could represent a trigger for metabolic dysfunctions such those related to diabetes. Despite the huge number of evidences at our disposal highlighting the role of TLRs' and inflammasomes' pathways in pancreatic islets dysfunction and T2DM, to date no drugs directly targeting TLRs or the NLRP3 inflammasome have been developed. However, clinical trials have been addressed, with positive results, at evaluating the efficacy of downstream products' blockers, such as Anakinra, a recombinant IL-1RA.

Further studies are warranted in unraveling the complex relationship between T2DM and immune system, and its implication for cardiovascular diseases.

\section{Author details}

Daniela Pedicino, Ada Francesca Giglio, Vincenzo Alessandro Galiffa, Francesco Trotta and Giovanna Liuzzo*

Institute of Cardiology, Catholic University, Rome, Italy

\section{References}

Acosta-Rodriguez EV, Napolitani G, Lanzavecchia A, \& Sallusto F. (2007). Interleukins 1beta and 6 but not transforming growth factor-beta are essential for the differentiation of interleukin 17-producing human T helper cells. Nat. Immunol, 8, 9, (Sep 2007), 942-949, 1529-2908

ADVANCE Collaborative Group, Patel A, MacMahon S, Chalmers J, Neal B, Billot L, Woodward M, Marre M, Cooper M, Glasziou P, Grobbee D, Hamet P, Harrap S, Heller S, Liu L, Mancia G, Mogensen CE, Pan C, Poulter N, Rodgers A, Williams B, Bompoint $\mathrm{S}$, de Galan BE, Joshi R \& Travert F. (2008). Intensive blood-glucose control and cardiovascular outcomes in patients with type 2 diabetes. $N$ Engl J Med,358, 24, (Jun 2008), 2560-2572

Al-Attas OS, Al-Daghri NM, Al-Rubeaan K, da Silva NF, Sabico SL, Kumar S, McTernan PG \& Harte AL. (2009). Changes in endotoxin levels in T2DM subjects on anti-diabetic therapies. Cardiovasc Diabetol , 8, (Apr 2009),20

\footnotetext{
${ }^{*}$ Corresponding Author
} 
Andriankaja OM, Barros SP, Moss K, Panagakos FS, DeVizio W, Beck J \& Offenbacher S. (2009). Levels of serum interleukin (IL)-6 and gingival crevicular fluid of IL-1beta and prostaglandin $\mathrm{E}(2)$ among non-smoking subjects with gingivitis and type 2 diabetes. $J$. Periodontol, 80,2, (Feb 2009),307-316

Arkan MC, Hevener AL, Greten FR, Maeda S, Li ZW, Long JM, Wynshaw-Boris A, Poli G, Olefsky J \& Karin M. (2005). IKK-beta links inflammation to obesity induced insulin resistance. Nat Med,11,2,(Feb 2005),191-198

Arnalich F, Hernanz A, López-Maderuelo D, Peña JM, Camacho J, Madero R, Vázquez JJ \& Montiel C. (2000). Enhanced acute-phase response and oxidative stress in older adults with type II diabetes. Horm Metab Res,32,10,(Oct 2000),407-412

Ashida K, Miyazaki K, Takayama E, Tsujimoto H, Ayaori M, Yakushiji T, Iwamoto N, Yonemura A, Isoda K, Mochizuki H, Hiraide H, Kusuhara M \& Ohsuzu F. (2005). Characterization of the expression of TLR2 (toll-like receptor 2) and TLR4 on circulating monocytes in coronary artery disease. J Atheroscler Thromb,12,1,(2005),53-60

Atkinson MA \& Maclaren NK.(1994). The pathogenesis of insulin-dependent diabetes mellitus. N Engl J Med, 331, 31, (Nov 1994),1428-3

Bahekar AA, Singh S, Saha S, Molnar J \& Arora R. (2007). The prevalence and incidence of coronary heart disease is significantly increased in periodontitis: a meta-analysis. Am Heart J,154,5,(Nov 2007),830-837

Banning AP, Westaby S, Morice MC, Kappetein AP, Mohr FW, Berti S, Glauber M, Kellett MA, Kramer RS, Leadley K, Dawkins KD \& Serruys PW. (2010). Diabetic and nondiabetic patients with left main and/or 3-vessel coronary artery disease: comparison of outcomes with cardiac surgery and paclitaxel-eluting stents. J Am Coll Cardiol, 55,11,(Mar 2010),1067-1075

Barzilay JI, Abraham L, Heckbert SR, Cushman M, Kuller LH, Resnick HE \& Tracy RP. (2001). The relation of markers of inflammation to the development of glucose disorders in the elderly: the Cardiovascular Health Study. Diabetes, 50,10,(Oct 2001),2384-2389

Best LG, Davidson M, North KE, MacCluer JW, Zhang Y, Lee ET, Howard BV, DeCroo S \& Ferrell RE. (2004). Prospective analysis of mannose-binding lectin genotypes and coronary artery disease in American Indians: the Strong Heart Study. Circulation,109,4,(Feb 2004),471-475

Bhaskar V, Yin J, Mirza AM, Phan D, Vanegas S, Issafras H, Michelson K, Hunter JJ \& Kantak SS. (2011). Monoclonal antibodies targeting IL-1 beta reduce biomarkers of atherosclerosis in vitro and inhibit atherosclerotic plaque formation in Apolipoprotein E-deficient mice. Atherosclerosis,216,2, (Jun 2011),313-320

Boden G. (2008). Ceramide: a contributor to insulin resistance or an innocent bystander? Diabetologia,51,7,(Jul 2008),1095-1096

Brooks-Worrell B \& Palmer JP. (2012). Immunology in the Clinic Review Series; focus on metabolic diseases: development of islet autoimmune disease in type 2 diabetes patients: potential sequelae of chronic inflammation. Clin Exp Immunol,167,1,(Jan 2012), $40-6$ 
Burke AP, Kolodgie FD, Zieske A, Fowler DR, Weber DK, Varghese PJ, Farb A \& Virmani R. (2004). Morphologic findings of coronary atherosclerotic plaques in diabetics: apostmortem study. Arterioscler Thromb Vasc Biol,24,7,(Jul 2004),1266-1271

Cai D, Yuan M, Frantz DF, Melendez PA, Hansen L, Lee J \& Shoelson SE. (2005). Local and systemic insulin resistance resulting from hepatic activation of IKK-beta and NFkappaB. Nat. Med,11,2,(Feb 2005),183-190

Cani PD, Amar J, Iglesias MA, Poggi M, Knauf C, Bastelica D, Neyrinck AM, Fava F, Tuohy KM, Chabo C, Waget A, Delmée E, Cousin B, Sulpice T, Chamontin B, Ferrières J, Tanti JF, Gibson GR, Casteilla L, Delzenne NM, Alessi MC \& Burcelin R. (2007). Metabolic endotoxemia initiates obesity and insulin resistance. Diabetes,56,7,(Jul 2007),1761-1772

Cantón A, Martinez-Cáceres EM, Hernández C, Espejo C, García-Arumí J \& Simó R. (2004). CD4-CD8 and CD28 expression in T cells infiltrating the vitreous fluid in patients with proliferative diabetic retinopathy: a flow cytometric analysis. Arch Ophthalmol, 122,5,(May 2004),743-749

Cantrill JA, D'Emanuele A, Dornan TL \& Garcia S. (1995). A survey of drug treatment and outcomes in diabetic patients with acute myocardial infarcts. J Clin Pharm Ther, 20,4,(Aug 1995),207-213

Caricilli AM, Nascimento PH, Pauli JR, Tsukumo DM, Velloso LA, Carvalheira JB \& Saad MJ. (2008). Inhibition of toll-like receptor 2 expression improves insulin sensitivity and signaling in muscle and white adipose tissue of mice fed a high-fat diet. J Endocrinol, 199,3,(Dec 2008),399-406

Chatenoud L, Bach JF. (2005). Regulatory T cells in the control of autoimmune diabetes: The case of the NOD mouse. Int Rev Immunol,24,3-4,(May-Aug 2005),247-267

Creely SJ, McTernan PG, Kusminski CM, Fisher M, Da Silva NF, Khanolkar M, Evans M, Harte AL \& Kumar S. (2007). Lipopolysaccharide activates an innate immune system response in human adipose tissue in obesity and type 2 diabetes. Am J Physiol Endocrinol Metab,292,3,(Mar 2007),E740-7

Dasu MR, Riosvelasco AC \& Jialal I. (2009). Candesartan inhibits Toll-like receptor expression and activity both in vitro and in vivo. Atherosclerosis,202,1,(Jan 2009),76-83

Dasu MR, Park S, Devaraj S \& Jialal I. (2009). Pioglitazone inhibits toll-like receptor expression and activity in human monocytes and db/db mice. Endocrinology,150,8,(Aug 2009),3457-3464

Davis BK, Wen H \& Ting JP. (2011). The inflammasome NLRs in immunity, inflammation, and associated diseases. Annu. Rev. Immunol,29,(Apr 2011),707-735

de Roos B, Rungapamestry V, Ross K, Rucklidge G, Reid M, Duncan G, Horgan G, Toomey S, Browne J, Loscher CE, Mills KH \& Roche HM. (2009). Attenuation of inflammation and cellular stress-related pathways maintains insulin sensitivity in obese type I interleukin-1 receptor knockout mice on a high-fat diet. Proteomics,9,12,(Jun 2009),32443256

Dinarello CA, Donath MY \& Mandrup-Poulsen T. (2010). Role of IL-1 $\beta$ in type 2 diabetes. Curr. Opin. Endocrinol. Diabetes Obes, 17,4,(Aug 2010),314-321

Duewell P, Kono H, Rayner KJ, Sirois CM, Vladimer G, Bauernfeind FG, Abela GS, Franchi L, Nuñez G, Schnurr M, Espevik T, Lien E, Fitzgerald KA, Rock KL,Moore KJ, Wright 
SD, Hornung V \& Latz E. (2010). NLRP3 inflammasomes are required for atherogenesis and activated by cholesterol crystals. Nature,464,7293,(Apr 2010),1357-1361

Duncan BB, Schmidt MI, Offenbacher S, Wu KK, Savage PJ \& Heiss G. (1999). Factor VIII and other hemostasis variables are related to incident diabetes in adults: The Atherosclerosis Risk in Communities (ARIC) study. Diabetes Care,22,5,(May 1999),767772

Ehses JA, Lacraz G, Giroix MH, Schmidlin F, Coulaud J, Kassis N, Irminger JC, Kergoat M, Portha B, Homo-Delarche F \& Donath MY. (2009). IL-1 antagonism reduces hyperglycemia and tissue inflammation in the type 2 diabetic GK rat. Proc. Natl. Acad. Sci. USA,106,33,(Aug 2009),13998-14003

Ehses JA, Meier DT, Wueest S, Rytka J, Boller S, Wielinga PY, Schraenen A, Lemaire K, Debray S, Van Lommel L, Pospisilik JA, Tschopp O, Schultze SM,Malipiero U, Esterbauer H, Ellingsgaard H, Rütti S, Schuit FC, Lutz TA, Böni-Schnetzler M, Konrad D \& Donath MY. (2010). Toll-like receptor 2-deficient mice are protected from insulin resistance and beta cell dysfunction induced by a high-fat diet. Diabetologia,53,8,(Aug 2010), 1795-1806

Eller K, Kirsch A, Wolf AM, Sopper S, Tagwerker A, Stanzl U, Wolf D, Patsch W, Rosenkranz AR \& Eller P. (2011). Potential Role of Regulatory T Cells in Reversing Obesity-Linked Insulin Resistance and Diabetic Nephropathy. Diabetes,60,11,(Nov 2011),2954-2962

Erridge C, Attina T, Spickett CM \& Webb DJ. (2007). A high-fat meal induces low-grade endotoxemia: evidence of a novel mechanism of postprandial inflammation. Am J Clin Nutr,86,5,(Nov 2007),1286-1292

Erridge C, Samani NJ.(2009). Saturated fatty acids do not directly stimulate Toll-like receptor signaling. Arterioscler Thromb Vasc Biol,29,11,(Nov 2009),1944-1949

Erridge C. (2011). The capacity of foodstuffs to induce innate immune activation of human monocytes in vitro is dependent on food content of stimulants of Toll like receptors 2 and 4. Br J Nutr,105,1,(Jan 2011),15-23

Erridge C. (2011). Accumulation of stimulants of Toll-like receptor (TLR)-2 and TLR4 in meat products stored at 5 degrees C. J Food Sci ,76,2,(Mar 2011),H72-9

Erridge C. (2011). Diet, commensals and the intestine as sources of pathogen-associated molecular patterns in atherosclerosis, type 2 diabetes and non-alcoholic fatty liver disease. Atherosclerosis,216, 1,(May 2011),1-6

Expert Committee on the Diagnosis and Classification of Diabetes Mellitus. (1997). Report of the Expert Committee on the Diagnosis and Classification of Diabetes Mellitus. Diabetes Care,20,7,(Jul 1997),1183-1197

Fang J \& Alderman MH. (2006). Impact of the increasing burden of diabetes on acute myocardial infarction in New York City: 1990-2000.Diabetes,55,3,(Mar 2006),768-773

Fernández-Real JM \& Ricart W. (2003). Insulin resistance and chronic cardiovascular inflammatory syndrome. Endocr Rev,24,3,(Jun 2003),278-301

Fernández-Real JM, Broch M, Richart C, Vendrell J, López-Bermejo A \& Ricart W. (2003). CD14 monocyte receptor, involved in the inflammatory cascade, and insulin sensitivity. J. Clin. Endocrinol. Metab,88,4,(Apr 2003),1780-1784 
Fernández-Real JM, Straczkowski M, Vendrell J, Soriguer F, Pérez Del Pulgar S, Gallart L, López-Bermejo A, Kowalska I, Manco M, Cardona F, García-Gil MM,Mingrone G, Richart C, Ricart W \& Zorzano A. (2006). Protection from inflammatory disease in insulin resistance: the role of mannan-binding lectin. Diabetologia,49,10,(Oct 2006),24022411

Fernández-Real JM \& Pickup JC. (2008). Innate immunity, insulin resistance and type 2 diabetes. Trends Endocrinol Metab,19,1,(Jan 2008),10-6

Festa A, D'Agostino R Jr, Howard G, Mykkänen L, Tracy RP, Haffner SM. (2000). Chronic subclinical inflammation as part of the insulin resistance syndrome: the Insulin Resistance Atherosclerosis Study (IRAS). Circulation,102,1,(Jul 2000),42-47

Festa A, D'Agostino R Jr, Tracy RP \& Haffner SM; Insulin Resistance Atherosclerosis Study. (2002). Elevated levels of acute-phase proteins and plasminogen activator inhibitor-1 predict the development of type 2 diabetes: the Insulin Resistance Atherosclerosis Study. Diabetes,51,4,(Apr 2002),1131- 1137

Feuerer M, Herrero L, Cipolletta D, Naaz A, Wong J, Nayer A, Lee J, Goldfine AB, Benoist C, Shoelson S \& Mathis D. (2009). Lean, but not obese, fat is enriched for a unique population of regulatory $\mathrm{T}$ cells that affect metabolic parameters. Nat. Med,15,8,(Aug 2009),930-939

Fischer H, Ellström P, Ekström K, Gustafsson L, Gustafsson M \& Svanborg C. (2007). Ceramide as a TLR4 agonist; a putative signalling intermediate between sphingolipid receptors for microbial ligands and TLR4. Cell Microbiol,9,5,(May 2007),1239-1251

Ford,ES \& Cogswell,ME (1999). Diabetes and serum ferritin concentration among US adults. Diabetes Care, 22, 12, (Dec 1999), 1978-1983

Ford,ES. (1999). Body mass index, diabetes, and C-reactive protein among US adults. Diabetes Care,22, 12, (Dec 1999), 1971-1977

Ford,ES. (2002). Leukocyte count, erythrocyte sedimentation rate, and diabetes incidence in a national sample of US adults. Am J Epidemiol,155,1,(Jan 2002),57-64

Freeman DJ, Norrie J, Caslake MJ, Gaw A, Ford I, Lowe GD, O'Reilly DS, Packard CJ \& Sattar N; West of Scotland Coronary Prevention Study. (2002). C-reactive protein is an independent predictor of risk for the development of diabetes in the West of Scotland Coronary Prevention Study. Diabetes,51,5,(May 2002),1596-1600

Fröhlich M, Imhof A, Berg G, Hutchinson WL, Pepys MB, Boeing H, Muche R, Brenner H \&Koenig W. (2000). Association between C-reactive protein and features of the metabolic syndrome: a population-based study. Diabetes Care,23,12,(Dec 2000),18351839

Geng HL, Lu HQ, Zhang LZ, Zhang H, Zhou L, Wang H \& Zhong RQ. (2006). Increased expression of Toll like receptor 4 on peripheral-blood mononuclear cells in patients with coronary arteriosclerosis disease. Clin Exp Immunol,143,2,(Feb 2006),269-273

Genuth S, Alberti KG, Bennett P, Buse J, Defronzo R, Kahn R, Kitzmiller J, Knowler WC, Lebovitz H, Lernmark A, Nathan D, Palmer J, Rizza R, Saudek C, Shaw J, Steffes M, Stern M, Tuomilehto J \&Zimmet P; Expert Committee on the Diagnosis and Classification of Diabetes Mellitus. (2003). Expert Committee on the Diagnosis and Classification of Diabetes Mellitus2, the Expert Committee on the Diagnosis and 
Classification of Diabetes Mellitus. Follow-up report on the diagnosis of diabetes mellitus. Diabetes Care,26,11,(Nov 2003),3160-3167

Ghoshal S, Witta J, Zhong J, de Villiers W \&Eckhardt E. (2009). Chylomicrons promote intestinal absorption of lipopolysaccharides. J Lipid Res, 50,1,(Jan 2009),90-97

Giubilato S, Liuzzo G, Brugaletta S, Pitocco D, Graziani F, Smaldone C, Montone RA, Pazzano V, Pedicino D, Biasucci LM, Ghirlanda G \& Crea F. (2011). Expansion of CD4+CD28null T-lymphocytes in diabetic patients: exploring new pathogenetic mechanisms of increased cardiovascular risk in diabetes mellitus. Eur Heart J,32,10,(May 2011),1214-1226

Giulietti A, van Etten E, Overbergh L, Stoffels K, Bouillon R \&Mathieu C. (2007). Monocytes from type 2 diabetic patients have a pro-inflammatory profile. 1,25-Dihydroxyvitamin D(3) works as antiinflammatory. Diabetes Res. Clin. Pract,77,1,(Jul 2007),47-57

Gorrell MD, Gysbers V \& McCaughan GW. (2001). CD26: a multifunctional integral membrane and secreted protein of activated lymphocytes. Scand J Immunol,54,3,(Sep 2001),249-264

Gu K, Cowie CC \&Harris MI. (1998). Mortality in adults wit and without diabetes in a national cohort of the U.S population, 1971-1993. Diabetes Care,21,7,(Jul 1998),1138-1145

Gubern C, López-Bermejo A, Biarnés J, Vendrell J, Ricart W \& Fernández-Real JM. (2006). Natural antibiotics and insulin sensitivity: the role of bactericidal and permeability increasing protein (BPI). Diabetes,55,1,(Jan 2006),216-224

Haffner SM, Lehto S, Rönnemaa T, Pyörälä K \& Laakso M. (1998). Mortality from coronary heart disease in subjects with type 2 diabetes and in nondiabetic subjects with and without prior myocardial infarction. N Engl J Med,339,4,(Jul 1998),229-234

Haffner SM, Mykkänen L, Festa A, Burke JP, Stern MP. (2000). Insulin-resistant prediabetic subjects have more atherogenic risk factors than insulin-sensitive prediabetic subjects: implications for preventing coronary heart disease during the prediabetic state. Circulation, 101, 9, (Mar 2000) 975-980

Hak AE, Pols HA, Stehouwer CD, Meijer J, Kiliaan AJ, Hofman A, Breteler MM \& Witteman JC. (2001). Markers of inflammation and cellular adhesion molecules in relation to insulin resistance in nondiabetic elderly: the Rotterdam Study. J Clin Endocr Metab,86,9,(Sep 2001),4398-4405

Harte AL, da Silva NF, Creely SJ, McGee KC, Billyard T, Youssef-Elabd EM, Tripathi G, Ashour E, Abdalla MS, Sharada HM, Amin AI, Burt AD, Kumar S, Day CP \& McTernan PG. (2010). Elevated endotoxin levels in non-alcoholic fatty liver disease. J Inflamm (Lond),30,(Mar 2010),7:15

Hatanaka E, Monteagudo PT, Marrocos MS \&Campa A. (2006). Neutrophils and monocytes as potentially important sources of proinflammatory cytokines in diabetes. Clin Exp Immunol,146,3,(Dec 2006),443-447

Hlatky MA, Boothroyd DB, Bravata DM, Boersma E, Booth J, Brooks MM, Carrié D, Clayton TC, Danchin N, Flather M, Hamm CW, Hueb WA, Kähler J, Kelsey SF, King SB, Kosinski AS, Lopes N, McDonald KM, Rodriguez A, Serruys P, Sigwart U, Stables RH, Owens DK \& Pocock SJ. (2009). Coronary artery bypass surgery compared with percutaneous coronary interventions for multivesseldisease: a collaborative analysis of 
individual patient data from ten randomized trials. Lancet, 373,9670,(Apr 2009),11901197

Holland WL, Brozinick JT, Wang LP, Hawkins ED, Sargent KM, Liu Y, Narra K, Hoehn KL, Knotts TA, Siesky A, Nelson DH, Karathanasis SK, Fontenot GK, Birnbaum MJ \& Summers SA. (2007). Inhibition of ceramide synthesis ameliorates glucocorticoid-, saturated-fat-, and obesity-induced insulin resistance. Cell Metab,5,3,(Mar 2007),167-179

Hundal RS, Petersen KF, Mayerson AB, Randhawa PS, Inzucchi S, Shoelson SE \& Shulman GI. (2002). Mechanism by which high-dose aspirin improves glucose metabolism in type 2 diabetes. J Clin Invest,109,10,(May 2002),1321-1326

Ilan Y, Maron R, Tukpah AM, Maioli TU, Murugaiyan G, Yang K, Wu HY \& Weiner HL. (2010). Induction of regulatory $\mathrm{T}$ cells decreases adipose inflammation and alleviates insulin resistance in ob/ob mice. Proc Natl Acad Sci USA,107,21,(May 2010),9765-9770

Ishikawa Y, Satoh M, Itoh T, Minami Y, Takahashi Y \& Akamura M. (2008). Local expression of toll-like receptor 4 at the site of ruptured plaques in patients with acute myocardial infarction. Clin Sci,115,4,(Aug 2008),133-140

Jagannathan M, McDonnell M, Liang Y, Hasturk H, Hetzel J, Rubin D, Kantarci A, Van Dyke TE, Ganley-Leal LM \& Nikolajczyk BS. (2010). Toll-like receptors regulate B cell cytokine production in patients with diabetes. Diabetologia,53,7,(Jul 2010),1461-1471

Ji Y, Liu J, Wang Z, Liu N \&Gou W. (2009). PPARgamma agonist, rosiglitazone, regulates angiotensin II-induced vascular inflammation through the TLR4- dependent signaling pathway. Lab Invest,89,8,(Aug 2009),887-902

Kahn SE, Hull RL \& Utzschneider KM. (2006). Mechanisms linking obesity to insulin resistance and type 2 diabetes. Nature,444,7121,(Dec 2006),840-846

Kannel WB \& McGee DL. (1979). Diabetes and cardiovascular disease: the Framingham study. JAMA,241,19,(May 1979),2035-2038

Kather,H. (1990). Pathways of purine metabolism in human adipocytes. Further evidence against a role of adenosine as an endogenous regulator of human fat cell function. J Biol Chem,265,1,(Jan 1990),96-102

Katsuki A, Sumida Y, Murashima S, Murata K, Takarada Y, Ito K, Fujii M, Tsuchihashi K, Goto H, Nakatani K \& Yano Y. (1998). Serum levels of tumor necrosis factor- $\alpha$ are increased in obese patients with noninsulin-dependent diabetes mellitus. J Clin Endocrinol Metab,83,3,(Mar 1998),859-862

Kawai T \& Akira S. (2010). The role of pattern-recognition receptors in innate immunity: update on Toll-like receptors. Nat Immunol,11,5,(May 2010),373-384

Kuwahata S, Fujita S, Orihara K, Hamasaki S, Oba R, Hirai H, Nagata K, Ishida S, Kataoka T, Oketani N, Ichiki H, Iriki Y, Saihara K, Okui H, Ninomiya Y \& Tei C. (2010). High expression level of Toll-like receptor 2 on monocytes is an important risk factor for arteriosclerotic disease. Atherosclerosis,209,1,(Mar 2010),248-254

Larsen CM, Faulenbach M, Vaag A, Vølund A, Ehses JA, Seifert B, Mandrup-Poulsen T \& Donath MY. (2007). Interleukin-1-receptor antagonist in type 2 diabetes mellitus. $N$. Engl. J. Med,356,15,(Apr 2007),1517-1526 
Larsen CM, Faulenbach M, Vaag A, Ehses JA, Donath MY \& Mandrup-Poulsen T. (2009). Sustained effects of interleukin-1 receptor antagonist treatment in type 2 diabetes. Diabetes Care,32,9,(Sept 2009),1663-1668

Laugerette F, Vors C, Géloën A, Chauvin MA, Soulage C, Lambert-Porcheron S, Peretti N, Alligier M, Burcelin R, Laville M, Vidal H \& Michalski MC. (2011). Emulsified lipids increase endotoxemia: possible role in early postprandial low-grade inflammation. $J$ Nutr Biochem,22,1,(Jan 2011),53-59

Lee JY, Sohn KH, Rhee SH \& Hwang D. (2001). Saturated fatty acids, but not unsaturated fatty acids, induce the expression of cyclooxygenase- 2 mediated through Toll-like receptor 4. J Biol Chem,276,20,(May 2001),16683-16689

Lee JY, Ye J, Gao Z, Youn HS, Lee WH, Zhao L, Sizemore N \& Hwang DH. (2003). Reciprocal modulation of Toll-like receptor-4 signaling pathways involving MyD88 and phosphatidylinositol 3- kinase/AKT by saturated and polyunsaturated fatty acids. J Biol Chem, 278,39,(Sept 2003),37041-37051

Lee JG, Kang DG, Yu JR, Kim Y, Kim J, Koh G \& Lee D. (2011). Changes in Adenosine Deaminase Activity in Patients with Type 2 Diabetes Mellitus and Effect of DPP-4 Inhibitor Treatment on ADA Activity. Diabetes Metab J,35,2,(Apr 2011),149-158

Leinonen E, Hurt-Camejo E, Wiklund O, Hultén LM, Hiukka A \& Taskinen MR. (2003). Insulin resistance and adiposity correlate with acute-phase reaction and soluble cell adhesion molecules in type 2 diabetes. Atherosclerosis,166,2,(Feb 2003),387-394

Liuzzo G, Kopecky SL, Frye RL, O'Fallon WM, Maseri A, Goronzy JJ \& Weyand CM. (1999). Perturbation of the T-cell repertoire in patients with unstable angina. Circulation,100,21,(Nov 1999),2135-2139

Liuzzo G, Goronzy JJ, Yang H, Kopecky SL, Holmes DR, Frye RL \& Weyand CM. (2000). Monoclonal T-cell proliferation and plaque instability in acute coronary syndromes. Circulation,101,25,(Jun 2000),2883-2888

Liuzzo G, Vallejo AN, Kopecky SL, Frye RL, Holmes DR, Goronzy JJ \& Weyand CM. (2001). Molecular fingerprint of interferon- $\gamma$ signalling in unstable angina. Circulation, 103,11,(Mar 2001),1509-1514

Liuzzo G, Biasucci LM, Trotta G, Brugaletta S, Pinnelli M, Digianuario G, Rizzello V, Rebuzzi AG, Rumi C, Maseri A \& Crea F. (2007). Unusual CD4+CD28null T lymphocytes and recurrence of acute coronary events. J Am Coll Cardiol,50,15,(Oct 2007), 1450-8

Loppnow H, Werdan K \& Buerke M. (2008). Vascular cells contribute to atherosclerosis by cytokine and innate immunity-related inflammatory mechanisms. Innate Immun,14,2,(Apr 2008),63-87

Maedler K, Sergeev P, Ris F, Oberholzer J, Joller-Jemelka HI, Spinas GA, Kaiser N, Halban PA \& Donath MY. (2008). Glucose-induced $\beta$ cell production of IL-1b contributes to glucotoxicity in human pancreatic islets. J. Clin. Invest, 110, 6, (Sep 2002), 851-860

Malmberg K, Yusuf S, Gerstein HC, Brown J, Zhao F, Hunt D, Piegas L, Calvin J, Keltai M \& Budaj A. (2000). Impact of diabetes on long-term prognosis in patients with unstable angina and non-Q-Wave myocardial infarction: results of the OASIS (Organization to 
Asses Strategies for Ischemic Syndromes) Registry. Circulation, 102, 9, (Aug 2000), 10141019

Masters SL, Dunne A, Subramanian SL, Hull RL, Tannahill GM, Sharp FA, Becker C, Franchi L, Yoshihara E, Chen Z, Mullooly N, Mielke LA, Harris J, Coll RC, Mills KH, Mok KH, Newsholme P, Nuñez G, Yodoi J, Kahn SE, Lavelle EC \& O'Neill LA. (2010). Activation of the NLRP3 inflammasome by islet amyloid polypeptide provides a mechanism for enhanced IL-1 $\beta$ in type 2 diabetes. Nature Immunol., 11, 10, (Oct 2010), 897-904

Methe H, Kim JO, Kofler S, Weis M, Nabauer M \& Koglin J. (2005). Expansion of circulating Toll-like receptor 4-positive monocytes in patients with acute coronary syndrome. Circulation, 111, 20, (May 2005), 2654-2661

Methe H, Kim JO, Kofler S, Nabauer M \& Weis M. (2005). Statins decrease toll-like receptor 4 expression and downstream signaling in human CD14+ monocytes. Arterioscler Thromb Vasc Biol, 25, 7, (Jul 2005), 1439-1445

Miettinen H, Lehto S, Salomaa V, Mähönen M, Niemelä M, Haffner SM, Pyörälä K \& Tuomilehto J.(1998). Impact of diabetes on mortality after the first myocardial infarction. The FINMONICA Myocardial Infarction Register Study Group. Diabetes Care,21,1, (Jan 1998),69-75

Miyazaki Y, Mahankali A, Matsuda M, Glass L, Mahankali S, Ferrannini E, Cusi K, Mandarino LJ \& DeFronzo RA. (2001). Improved glycemic control and enhanced insulin sensitivity in type 2 diabetic subjects treated with pioglitazone. Diabetes Care, 24, 4, (Apr 2001), 710-719

Miyazaki Y, Glass L, Triplitt C, Matsuda M, Cusi K, Mahankali A, Mahankali S, Mandarino LJ \& DeFronzo RA. (2001) Effect of rosiglitazone on glucose and non-esterified fatty acid metabolism in type II diabetic patients. Diabetologia, 44, 12, (Dec 2001), 2210-2219

Mizoguchi E, Orihara K, Hamasaki S, Ishida S, Kataoka T, Ogawa M, Saihara K, Okui H, Fukudome T, Shinsato T, Shirasawa T, Ichiki H, Kubozono T, Ninomiya Y, Otsuji Y \& Tei C. (2007). Association between Toll-like receptors and the extent and severity of coronary artery disease in patients with stable angina. Coron Artery Dis, 18, 1, (Feb 2007), 31-38.

Monaco C, Gregan SM, Navin TJ, Foxwell BM, Davies AH \& Feldmann M. (2009). Toll-like receptor-2 mediates inflammation and matrix degradation in human atherosclerosis. Circulation, 120, 24, (Dec 2009), 2462-2469

Moreno PR \& Fuster V. (2004) New aspects in the pathogenesis of diabetic atherothrombosis. J Am Coll Cardiol., 44, 12, (Dec2004),2293-2300

Morris MF. (2003). Insulin receptor signaling and regulation, In: Textbook of Diabetes. $3 r d$ ed. Pickup JC, Williams G, p. 14.1-14.17, Eds. Oxford, U.K.

Müller S, Martin S, Koenig W, Hanifi-Moghaddam P, Rathmann W, Haastert B, Giani G, Illig T, Thorand B \& Kolb H. (2002). Impaired glucose tolerance is associated with increased serum concentrations of interleukin 6 and co-regulated acute phase proteins but not TNF- $\alpha$ or its receptors. Diabetologia, 45, 6, (Jun 2002),805-812

Murcia AM, Hennekens CH, Lamas GA, Jiménez-Navarro M, Rouleau JL, Flaker GC, Goldman S, Skali H, Braunwald E \& Pfeffer MA. (2004). Impact of diabetes on mortality 
in patients with myocardial infarction and left ventricular dysfunction. Arch Intern Med,164, 20, (Nov 2004), 2273-2279

Nakajima T, Schulte S, Warrington KJ, Kopecky SL, Frye RL, Goronzy JJ \& Weyand CM. (2002). T-cell-mediated lysis of endothelial cells in acute coronary syndromes. Circulation, 105, 5, (Feb 2002), 570-575

Nakanishi N, Yoshida H, Matsuo Y, Suzuki K \& Tatara K. (2002). White blood-cell count and the risk of impaired fasting glucose or type II diabetes in middle-aged Japanese men. Diabetologia, 45, 1, (Jan 2002), 42-48

Niessner A, Steiner S, Speidl WS, Pleiner J, Seidinger D, Maurer G, Goronzy JJ, Weyand CM, Kopp CW, Huber K, Wolzt M \& Wojta J. (2006). Simvastatin suppresses endotoxininduced upregulation of toll-like receptors 4 and 2 in vitro. Atherosclerosis, 189, 2, (Dec 2006), 408-413

Nikolajczyk BS, Jagannathan-Bogdan M, Shin H \& Gyurko R. (2011). State of the union between metabolism and the immune system in type 2 diabetes. Genes Immun, 12, 4, (Jun 2011), 239-250

Oka S, Yoshihara E, Bizen-Abe A, Liu W, Watanabe M, Yodoi J \& Masutani H. (2009). Thioredoxin binding protein-2/thioredoxin-interacting protein is a critical regulator of insulin secretion and peroxisome proliferator-activated receptor function. Endocrinology, 150, 3, (Mar 2009), 1225-1234

Osborn O, Brownell SE, Sanchez-Alavez M, Salomon D, Gram H \& Bartfai T. (2008). Treatment with an Interleukin 1 beta antibody improves glycemic control in dietinduced obesity. Cytokine,44,1, (Oct 2008),141-148

Otsui K, Inoue N, Kobayashi S, Shiraki R, Honjo T, Takahashi M, Hirata K, Kawashima S \& Yokoyama M. (2007). Enhanced expression of TLR4 in smooth muscle cells in human atherosclerotic coronary arteries. Heart Vessels, 22, 6, (Nov 2007), 416-422

Parikh H, Carlsson E, Chutkow WA, Johansson LE, Storgaard H, Poulsen P, Saxena R, Ladd C, Schulze PC, Mazzini MJ, Jensen CB, Krook A, Björnholm M, Tornqvist H, Zierath JR, Ridderstråle M, Altshuler D, Lee RT, Vaag A, Groop LC \& Mootha VK. (2007). TXNIP regulates peripheral glucose metabolism in humans. PLoS Med, 4, 5, (May 2007) e158

Patel A, MacMahon S, Chalmers J, Neal B, Billot L, Woodward M, Marre M, Cooper M, Glasziou P, Grobbee D, Hamet P, Harrap S, Heller S, Liu L, Mancia G, Mogensen CE, Pan C, Poulter N, Rodgers A, Williams B, Bompoint S, de Galan BE, Joshi R \& Travert F, ADVANCE Collaborative Group. (2008). Intensive blood-glucose control and cardiovascular outcomes in patients with type 2 diabetes. NEJM,358,24,(Jun 2008),25602572

Pickup JC, Chusney GC, Thomas SM \& Burt D. (2000). Plasma interleukin-6, tumor necrosis factor alpha and blood cytokine production in types 2 diabetes. Life Sci, 67, 3, (Jun 2000),291-300

Pickup JC. (2003). Inflammation and activated innate immunity in the pathogenesis of type 2 diabetes. Diabetes Care, 27, 3, (Mar 2004), 813-823

Pitocco D, Giubilato S, Zaccardi F, Di Stasio E, Buffon A, Biasucci LM, Liuzzo G, Crea F \& Ghirlanda G. (2009). Pioglitazone reduces monocyte activation in type 2 diabetes. Acta Diabetol, 46,1, (Mar 2009), 75-77. 
Pradhan AD, Manson JE, Rifai N, Buring JE \& Ridker PM. (2001). C-reactive protein, interleukin 6, and risk of developing type 2 diabetes mellitus. JAMA, 286, 3, (Jul 2001),327-334

Prakash MS, Chennaiah S, Murthy YS, Anjaiah E, Rao SA \& Suresh C. (2006). Altered adenosine deaminase activity in type 2 diabetes mellitus. JIACM,7, (2006), 114-117

Rajamäki K, Lappalainen J, Oörni K, Välimäki E, Matikainen S, Kovanen PT \& Eklund KK. (2010). Cholesterol crystals activate the NLRP3 inflammasome in human macrophages: a novel link between cholesterol metabolism and inflammation. PLoSONE, 5, 7, (Jul 2010), e11765

Randolph DA \& Fathman CG. (2006). CD4 ${ }^{+} \mathrm{CD} 25^{+}$regulatory T cells and their therapeutic potential. Annu Rev Med, 57, (2006), 381-402

Reimers JI. (1998). Interleukin-1 beta induced transient diabetes mellitus in rats. A model of the initial events in the pathogenesis of insulin-dependent diabetes mellitus? Dan. Med. Bull., 45, 2 (Apr 1998), 45:157-180.

Richardson AP \& Tayek JA. (2002). Type 2 diabetic patients may have a mild form of an injury response: a clinical research center study. Am J Physiol, 282,6, (Jun 2002); 12861290

Rodriguez-Moran M \& Guerrero-Romero F. (1999). Increased levels of C-reactive protein in noncontrolled type II diabetic subjects. J Diabetes Complications,13, 4, (Jul-Aug 1999),211215

Sakkinen PA, Wahl P, Cushman M, Lewis MR \& Tracey RP. (2000) Clustering of procoagulation, inflammation and fibrinolysis variables with metabolic factors in insulin resistance syndrome. Am J Epidemiol,152, 10, (May 2000), 897-907

Sato K, Niessner A, Kopecky SL, Frye RL, Goronzy JJ \& Weyand CM. (2006). TRAILexpressing $\mathrm{T}$ cells induce apoptosis of vascular smooth muscle cells in the atherosclerotic plaque. J Experim Med, 203, 1, (Jan 2006), 239-250

Schmidt MI, Duncan BB, Sharrett AR, Lindberg G, Savage PJ, Offenbacher S, Azambuja MI, Tracy RP \& Heiss G. (1999). Markers of inflammation and prediction of diabetes mellitus in adults (Atherosclerosis Risk in Communities study): a cohort study. Lancet, 353, 9165, (May 1999), 1649-1652

Schramm TK, Gislason GH, Køber L, Rasmussen S, Rasmussen JN, Abildstrøm SZ, Hansen ML, Folke F, Buch P, Madsen M, Vaag A \& Torp-Pedersen C. (2008). Diabetes patients requiring glucose-lowering therapy and nondiabetics with a prior myocardial infarction carry the same cardiovascular risk: a population study of 3.3 million people. Circulation, 117, 15, (Apr 2008), 1945-1954

Schroder K \& Tschopp J. (2010). The inflammasomes. Cell, 140, 6, (Mar 2010), 821-832

Schwartz EA, Zhang WY, Karnik SK, Borwege S, Anand VR, Laine PS, Su Y \& Reaven PD. (2010). Nutrient modification of the innate immune response: a novel mechanism by which saturated fatty acids greatly amplify monocyte inflammation. Arterioscler Thromb Vasc Biol, 30, 4, (Apr 2010), 802-808

Seino, S \& Study Group of Comprehensive Analysis of Genetic Factors in Diabetes Mellitus. (2001). S20G mutation of the amylin gene is associated with type II diabetes in Japanese. 
Study Group of Comprehensive Analysis of Genetic Factors in Diabetes Mellitus. Diabetologia,44, 7, (Jul 2001), 906-909

Shah C, Yang G, Lee I, Bielawski J, Hannun YA \& Samad F. (2008). Protection from high fat diet-induced increase in ceramide in mice lacking plasminogen activator inhibitor $1 . J$ Biol Chem, 283 ,20, (May 2008), 13538-13548

Shindler DM, Palmeri ST, Antonelli TA, Sleeper LA, Boland J, Cocke TP \& Hochman JS. (2000). Diabetes mellitus in cardiogenic shock complicated acute myocardial infarction: a report from the SHOCK trial registry. Should we emergently revascularize occluded coronaries for cardiogenic shock? J Am Coll Cardiol, 36, 3 (Suppl A), (Sep 2000), 10971103.

Shinohara M, Hirata K, Yamashita T, Takaya T, Sasaki N, Shiraki R, Ueyama T, Emoto N, Inoue $\mathrm{N}$, Yokoyama M \& Kawashima S.(2007). Local overexpression of toll-like receptors at the vessel wall induces atherosclerotic lesion formation: synergism of TLR2 and TLR4. Arterioscler Thromb Vasc Biol, 27, 11, (Nov 2007), 2384-2391

Shiraki R, Inoue N, Kobayashi S, Ejiri J, Otsui K, Honjo T, Takahashi M, Hirata K, Yokoyama M \& Kawashima S. (2006). Toll-like receptor 4 expressions on peripheral blood monocytes were enhanced in coronary artery disease even in patients with low Creactive protein. Life Sci, 80, 1, (Dec 2006), 59-66

Snijder MB, Dekker JM, Visser M, Stehouwer CDA, van Hinsberg VWM, Bouter LM \& Heine RJ. (2001). C-reactive protein and diabetes mellitus type 2. Diabetologia, 44, (2001), 115

Spranger J, Kroke A, Möhlig M, Hoffmann K, Bergmann MM, Ristow M, Boeing H \& Pfeiffer AF. (2003). Inflammatory cytokines and the risk to develop type 2 diabetes: results of the prospective population-based European Prospective Investigation into Cancer and Nutrition (EPIC)-Potsdam study. Diabetes, 52, 3, (Mar 2003), 812-817

Sriharan M, Reichelt AJ, Opperman ML, Duncan BB, Mengue SS, Crook MA \& Schmidt MI. (2002). Total sialic acid and associated elements of the metabolic syndrome in women with and without previous gestational diabetes. Diabetes Care,25, 8, (Aug 2002), 13311335

Stienstra R, Joosten LA, Koenen T, van Tits B, van Diepen JA, van den Berg SA, Rensen PC, Voshol PJ, Fantuzzi G, Hijmans A, Kersten S, Müller M, van den Berg WB, van Rooijen N, Wabitsch M, Kullberg BJ, van der Meer JW, Kanneganti T, Tack CJ, \& Netea MG. (2010). The inflammasome-mediated caspase-1 activation controls adipocyte differentiation and insulin sensitivity. Cell Metab, 12, 6, (Dec 2010), 593-605

Stienstra R, van Diepen JA, Tack CJ, Zaki MH, van de Veerdonk FL, Perera D, Neale GA, Hooiveld GJ, Hijmans A, Vroegrijk I, van den Berg S, Romijn J, Rensen PC, Joosten LA, Netea MG \& Kanneganti TD.(2011). Inflammasome is a central player in the induction of obesity and insulin resistance. Proc Natl Acad Sci, 108, 37, (Sep 2011), 15324-15329

Stoll LL, Denning GM \& Weintraub NL.(2006). Endotoxin, TLR4 signaling and vascular inflammation: potential therapeutic targets in cardiovascular disease. Curr Pharm Des, 12,32 , (2006),4229-4245

Strowig T, Henao-Mejia J, Elinav E \& Flavell R. (2012). Inflammasomes in health and disease. Nature, 481, 7381, (Jan 2012),278-286 
Summerfield JA, Sumiya M, Levin M \& Turner MW. (1997). Association of mutations in mannose binding protein gene with childhood infection in consecutive hospital series. BMJ, 314, 7089, (Apr 1997),1229-32

Takeda K \& Akira S. (2004). TLR signaling pathways. Semin Immunol, 16, 1, (Feb 2004), 3-9

Tanaka T, Itoh H, Doi K, Fukunaga Y, Hosoda K, Shintani M, Yamashita J, Chun TH, Inoue M, Masatsugu K, Sawada N, Saito T, Inoue G, Nishimura H,Yoshimasa Y \& Nakao K.(1999). Down regulation of peroxisome proliferator-activated receptor- $\gamma$ expression by inflammatory cytokines and its reversal by thiazolidinediones. Diabetologia, 42, 6, (Jun 1999),702-710

Temelkova-Kurktschiev T, Henkel E, Koehler C, Karrei K \& Hanefield M. (2002). Subclinical inflammation in newly detected type II diabetes and impaired glucose tolerance. Diabetologia, 45, 1, (Jan 2002), 151

Temelkova-Kurktschiev T, Siegert G, Bergmann S, Henkel E, Koehler C, Jaross W \& Hanefeld M. (2002). Subclinical inflammation is strongly related to insulin resistance but not insulin secretion in a high risk population for diabetes. Metabolism, 51, 6, (Jun 2002),743-749

Thorand B, Löwel H, Schneider A, Kolb H, Meisinger C, Fröhlich M \& Koenig W. (2003). Creactive protein as a predictor for incident diabetes mellitus among middle-aged men: results from the MONICA Augsburg cohort study. Arch Intern Med, 163, 1, (Jan 2003), 93-99

Tsukumo DM, Carvalho-Filho MA, Carvalheira JB, Prada PO, Hirabara SM, Schenka AA, Araújo EP, Vassallo J, Curi R, Velloso LA \& Saad MJ. (2007). Loss-of-function mutation in Toll-like receptor 4 prevents diet-induced obesity and insulin resistance. Diabetes, 56, 8, (Aug 2007), 1986-1998

UKPDS Group. (1998). Effect of intensive blood-glucose control with metformin on complications in overweight patients with type 2 diabetes (UKPDS 34). Lancet, 352, 9131, (Sep 1998), 854-865

Vandanmagsar B, Youm YH, Ravussin A, Galgani JE, Stadler K, Mynatt RL, Ravussin E, Stephens JM \& Dixit VD. (2011). The NLRP3 inflammasome instigates obesity-induced inflammation and insulin resistance. Nature Med, 17, 2, (Feb 2011), 179-188

Versteeg D, Hoefer IE, Schoneveld AH, de Kleijn DP, Busser E, Strijder C, Emons M, Stella PR, Doevendans PA \& Pasterkamp G. (2008). Monocyte toll-like receptor 2 and 4 responses and expression following percutaneous coronary intervention: association with lesion stenosis and fractional flow reserve. Heart, 94, 6, (Jun 2008), 770-776

Visser M, Bouter LM, McQuillan GM, Wener MH \& Harris TB. (1999). Elevated C-reactive protein levels in overweight and obese adults. JAMA, 282, 22, (Dec 1999), 2131-2135

Vozarova B, Weyer C, Lindsay RS, Pratley RE, Bogardus C \& Tataranni PA. (2002). High white blood cell count is associated with a worsening of insulin sensitivity and predicts the development of type 2 diabetes. Diabetes,51, 2, (Feb 2002), 455-461

Wen H, Gris D, Lei Y, Jha S, Zhang L, Huang MT, Brickey WJ \& Ting JP. (2011). Fatty acidinduced NLRP3-ASC inflammasome activation interferes with insulin signaling. Nat Immunol, 12, 5, (May 2011), 408-415. 
Weyer C, Yudkin JS, Stehouwer CD, Schalkwijk CG, Pratley RE \& Tataranni PA. (2002). Humoral markers of inflammation and endothelial dysfunction in relation to adiposity and in vivo insulin action in Pima Indians. Atherosclerosis,161, 1, (Mar 2002), 233- 242

Wild S, Roglic G, Green A, Sicree R \& King H. (2004). Global prevalence of diabetes: Estimates for the year 2000 and projections for 2030. Diabetes Care, 27, 5, (May 2004), 1047

Winer S, Chan Y, Paltser G, Truong D, Tsui H, Bahrami J, Dorfman R, Wang Y, Zielenski J, Mastronardi F, Maezawa Y, Drucker DJ, Engleman E, Winer D \& Dosch HM. (2009). Normalization of obesity-associated insulin resistance through immunotherapy. Nat. Med., 15, 8, (Aug 2009), 921-929.

Winer S, Paltser G, Chan Y, Tsui H, Engleman E, Winer D \& Dosch HM. (2009). Obesity predisposes to Th17 bias. Eur. J. Immunol., 39, 9, (Sep 2009), 2629-2635

Winkler G, Salamon F, Salamon D, Speer G, Simon K \& Cseh K. (1998). Elevated tumor necrosis factor alpha levels can contribute to the insulin resistance in type II (noninsulin-dependent) diabetes and obesity. Diabetologia, 41, 7, (Jul 1998), 860-862

Wyss CA, Neidhart M, Altwegg L, Spanaus KS, Yonekawa K, Wischnewsky MB, Corti R, Kucher N, Roffi M, Eberli FR, Amann-Vesti B, Gay S, von Eckardstein A,Lüscher TF \& Maier W. (2010).Cellular actors, Toll-like receptors, and local cytokine profile in acute coronary syndromes. Eur Heart J, 31, 12, (Jun 2010), 1457-1469

$\mathrm{Xu} \mathrm{XH}$, Shah PK, Faure E, Equils O, Thomas L, Fishbein MC, Luthringer D, Xu XP, Rajavashisth TB, Yano J, Kaul S \& Arditi M. (2001). Toll-like receptor-4 is expressed by macrophages in murine and human lipid-rich atherosclerotic plaques and upregulated by oxidized LDL. Circulation, 104, 25, (Dec 2001), 3103-3108

Yang L, Anderson DE, Baecher-Allan C, Hastings WD, Bettelli E, Oukka M, Kuchroo VK \& Hafler DA. (2008). IL-21 and TGF-beta are required for differentiation of human Th17 cells. Nature, 454, 7202, (Jul 2008) 350-352

Yonekawa K, Neidhart M, Altwegg LA, Wyss CA, Corti R, Vogl T, Grigorian M, Gay S, Lüscher TF \& Maier W. (2011). Myeloid related proteins activate Toll-like receptor 4 in human acute coronary syndromes. Atherosclerosis, 218, 2, (Oct 2011), 486-92.

Yudkin JS, Stehouwer CD, Emeis JJ \& Coppack SW. (1999). C-reactive protein in healthy subjects: association with obesity, insulin resistance, and endothelial dysfunction: a potential role for cytokines originating from the adipose tissue? Arterioscler Thromb Vasc Biol , 19, 4, (Apr 1999), 972-978

Zhou R, Tardivel A, Thorens B, Choi I \& Tschopp J. (2010). Thioredoxin-interacting protein links oxidative stress to inflammasome activation. Nature Immunol, 11, 2, (Feb 2010) 136140 . 